\title{
Learning Difficulties for Retarded Students: Case Studies on Biology Subjects in High School
}

\author{
$1^{\text {st }}$ Lissa \\ Biology Education Departmen, \\ Universitas Wiralodra \\ Jl. Ir. H. Djuanda Km.03, Indramayu, \\ Indonesia \\ Lissa@unwir.ac.id \\ $4^{\text {th }}$ Nerih \\ Biology Education Departmen \\ Universitas Wiralodra \\ J1. Ir. H. Djuanda Km.03, Indramayu, \\ Indonesia
}

\author{
$2^{\text {nd }}$ I B Minarti \\ Education Biology Department, \\ University of PGRI Semarang \\ Jl. Sidodadi timur No. 24- Dr. Cipto, \\ Semarang 40154, Indonesia
}

\author{
$3^{\text {rd }}$ N Subkhi \\ Biology Education Departmen \\ Universitas Wiralodra \\ Jl. Ir. H. Djuanda Km.03, Indramayu, \\ Indonesia
}

\begin{abstract}
In this paper, we analyse the internal and external factors that cause learning difficulties for students with mental retardation. The research subjects were 7 mentally retarded students, to carry out this study the observation sheet was designed to observe students while at school, questionnaire for students and teachers, and interview sheets for students, teachers and parents. The results obtained revealed that internal factors such as motivation and interest had no effect as well as for readiness and attention, while the extrenal factor, which is the school and family environment, influences. So it can be concluded that what affects the learning biology difficulties of retarded students is external factors.
\end{abstract}

\section{Keywords-Learning, retarded, Biology, High School}

\section{INTRODUCTION}

Mental retardation is a mental disorder that can inhibit cognitive and psychomotor functions of a person [1]. The development and growth of mental retardation experience physical or intellectual mental-intellectual social or emotional disorders or deviations, so they need special services [2]. That is due to factors, the first genetic factors such as Down syndrome, William syndrome, Fragile X syndrome and Prader-Willi syndrome, and secondly environmental factors that influence brain development [3]. The limitations of mental retardation have caused it to be slow in responding to stimuli provided by the environment to it, including in class learning [4]. Developmental students need special education, the learning environment plays a role in giving positive responses that support students through the learning process. Parents and teachers are included in the learning environment [5].

Biology generally has an abstract concept. There are many drawings and diagrams to explain the concept, so it needs analytical skills, predictions, and the ability to draw conclusions to be able to understand them [6]. While mentally retarded students have mental disabilities that cause Intelligence Quotient (IQ) and psychomotor limited [7]. Learning biology that is not varied and full of concepts adds to the boredom of students in the classroom. And that is no different when students practice in the laboratory, students can not be controlled because of the many psychomotor demanded by the teacher [8].

The repetition method is an effective method applied for teaching mentally disabled students' concepts, because it makes them remember better [9]. Students' thinking skills cannot be determined by one learning stage, but stages are required [10]. Learning biology requires careful thought, because many abstract concepts and processes [11]. Students get misconceptions when learning abstract concepts [12]. While mentally retarded children find it difficult to focus on something, so the learning outcomes are below standard [7]. The results of interviews with teachers in schools stated that biology is a subject that is not attractive to retarded students because many concepts are abstract and boring, and that causes their biology learning outcomes to be low.

Intellectual disability in mentally retarded students makes it hampered in activities, including when studying [13]. According to the American Psychiatric Association (APA) [14], Mental retardation is classified into four: first, mild (IQ <70) in this category students are able to be educated, trained and can take care of themselves, secondly, moderate (IQ 35-50), students can be educated and trained but physical abnormalities have emerged as innate, third, Severe (IQ 20-35), students need guarding because they cannot take care of themselves, fourth, profound (IQ> 20) has serious disabilities, both physical and intelligence. Learning difficulties in retarded students vary depending on the IQ category of the student. Student IQ levels are inversely proportional to student learning difficulties, low IQ has high learning difficulties, and vice 
versa [15]. Learning difficulties are multidimensional syndromes that manifest as specific learning difficulties, hyperactivity or distractibility and emotional problems [3]. Difficulties in learning mental retardation are divided into difficulties in concept, language and arithmetic [15]. Based on research on biology learning difficulties, it is found that evolution is a concept that is not well understood by most students [16]. Students have difficulty interpreting diagrams due to lack of basic knowledge and incompetent in connecting between basic knowledge, spatial ability and ability to remember [11]. Students have difficulty asking questions in class when finding concepts that are not of interest and are abstract [17]. Difficulty in understanding cell concepts due to conventional classroom teaching methods [6]. These results, concluded the difficulty of learning biology is a concept. Research to analyze the factors of learning difficulties in biology in retarded students has not been done much.

Difficulty learning for mentally retarded students is a complex problem, not only about cognitive limitations, but also about mental-psychological limitations [18]. The difficulty of learning in this study is the difficulty of the concept. Factors causing learning difficulties for mentally retarded students, first internal factors namely interest and motivation, readiness and attention. the two external factors are the school environment [19]. Motivation is the drive to do something that comes from within the individual and from outside [20]. Internal motivation is stronger than external motivation because it is not influenced by anything outside of him [18]. When mentally retarded students feel comfortable and facilitated with the environment, it will have good learning motivation [21]. Learning readiness can be interpreted as an attitude of being ready to receive material, so students before starting learning have prepared both the material and the learning equipment. Attention is defined as focus when learning takes place, while mentally retarded students find it difficult to focus on one point. School environment, including the learning process, teachers, peers and other environments [5].

\section{METHOD}

The sample of this study were 7 mentally retarded students, and 1 teacher. Students come from Indramayu district with an age range of 17-18 years, of which 4 students are female and 3 male students. IQ samples of mentally retarded students at the "mild" and "moderate" levels who are able to be educated. Sampling technique with "purposive sampling" with the aim of getting retarded students who have homogeneous IQ levels, so that it can describe the difficulties experienced by one category. The teacher used as the research sample is a mentally retarded classroom teacher. The sample used in this study is small in size, but for qualitative research sample size is not a problem because the rule of sampling becomes sufficient when data saturation is achieved through repetition of themes, issues, and stories from the interviewees [22].

In this study we used instruments, the first observation sheet was used to observe students during the learning process. This observation sheet contains 6 statements about the factors of student learning difficulties. The researcher acts directly as an observer during the study, with the aim of being able to add questions if needed [23]. To validate the data, the researcher added a second instrument, which was a questionnaire in the form of an open questionnaire and was given to the teacher. Questionnaire refers to the measurement scale according to Likert. In addition, the researcher also uses the interview sheet as the third instrument. Interview sheets that are used are structured types, in which questions have been prepared by researchers [22]. During the research, the researcher recorded important events through field notes. And the field notes are used as the fourth instrument in the study. The use of diverse instruments as a research effort to ensure the validity and reliability of research data. Instrument triangulation can increase the credibility of research data [23].

This research is included in qualitative research with case study method [22]. analyze the factors of learning disability biology for mentally disabled students in schools for students with special needs in Indramayu, Indonesia. Difficulty factors analyzed are internal factors consisting of motivation, learning readiness and attention. External factors such as school environment [19]. The study was conducted for 1 month. At school researchers observe the state of the school, social interaction, and the learning process. Observations in class, researchers observe during two meetings, researchers act as observers. Teachers conduct learning management as usual, without interference from researchers, so students do not feel being observed by strangers. After learning is finished, students and teachers will be interviewed separately by researchers to ask the same questions. And teachers will also be asked to fill out questionnaires as data reinforcement. During the research, the researcher must have the sharpness of the analysis of extraordinary events in the school related to the focus of the study, then he made a field note.

Data in this study were analyzed using descriptive statistics in the form of scoring and percentage. Data visualization uses Diagrams and Tables to facilitate interpretation.

\section{RESULTS AND DISCUSSION}

The learning difficulties of retarded students are not only due to intelligence factors, but also other factors such as motivation, learning readiness and the environment [1]. The results of the study that illustrate these factors are explained in Figure 1 and Table I. 


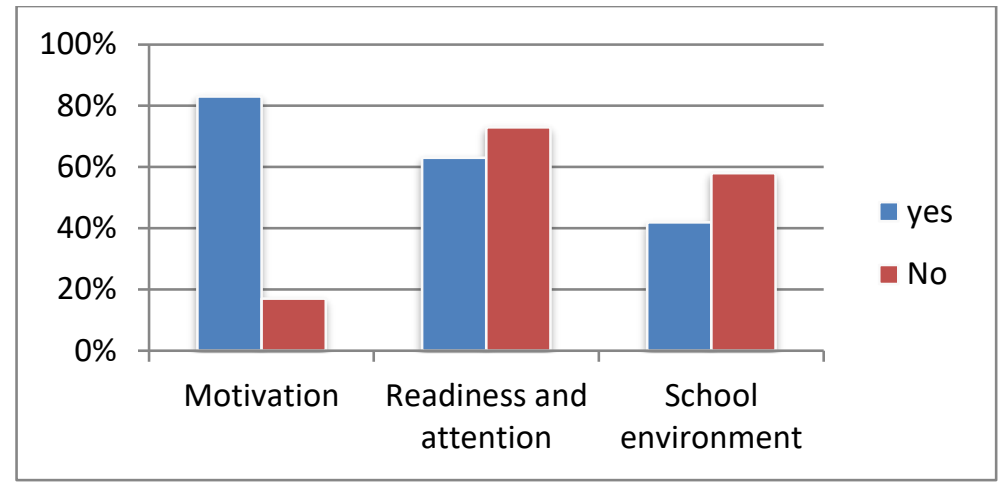

Fig. 1. Observation Results of Learning Difficulties in Biology of Students with Developmental Disabilities

TABLE I. RESULTS OF QUESTIONNAIRE DIFFICULTIES IN LEARNING BIOLOGY

\begin{tabular}{|l|l|r|r|r|r|}
\hline No & Indicators & $\begin{array}{c}\text { Strongly } \\
\text { agree }\end{array}$ & $\begin{array}{c}\text { Somewhat } \\
\text { agree }\end{array}$ & \multicolumn{1}{c|}{$\begin{array}{c}\text { Somewhat } \\
\text { disagree }\end{array}$} & $\begin{array}{c}\text { Strongly } \\
\text { disagree }\end{array}$ \\
\hline 1 & Motivation & $75 \%$ & $12,50 \%$ & $4,17 \%$ & $8,33 \%$ \\
\hline & & & & & \\
2 & Readiness and attention & $33,33 \%$ & $16,67 \%$ & $38,89 \%$ & $11,11 \%$ \\
\hline 3 & School Environment & $44,44 \%$ & $22,22 \%$ & $11,11 \%$ & $22,22 \%$ \\
\hline
\end{tabular}

Figure 1 explains that internal factors do not affect learning difficulties, while external factors vice versa. The percentage of motivation of $83 \%$ shows that retarded students have high motivation during biology learning. Thus motivation does not affect the learning difficulties of mentally disabled students [8]. Motivation is defined as intentional involvement in cognitive activities which play an important part in the learning process, determine what part we choose to study, and how well we study the information provided [20]. The percentage of motivation is explained in more detail through Figure 1.

TABLE II. OBSERVATION RESULTS LEARNING DIFFICULTIES ASPECTS OF INTEREST AND MOTIVATION

\begin{tabular}{|c|c|c|}
\hline No & Question & Precentage \\
\hline 1 & Always pay attention to the teacher during learning & $67 \%$ \\
\hline 2 & already in class before learning starts (on time) & $100 \%$ \\
\hline
\end{tabular}

The motivational data in Table II states $67 \%$ in the question 1. always pay attention during learning and $100 \%$ on the question 2. already in class before learning starts (on time). This was confirmed by the results of the teacher's questionnaire which stated $75 \%$ strongly agreed with the positive statement. During the learning process not all students focus on the teacher's explanation, because mentally disabled students cannot focus on one incident / event [7]. 33\% of mentally disabled students do their own activities. Mental students are capable of educating, are more easily directed and guided while learning, therefore their motivation is quite high [15].

Student learning is driven by mental strength. Mental strength is in the form of desires and attention, sometimes there are desires that activate, move, channel and direct the attitudes and behavior of individuals in learning [24]. Discipline of students, timeliness of class entry is very good, this is due to supporting factors from parents. The role of parents as a factor in the learning environment is very large for mentally retarded students because they need help and motivation from them more than students in general [25]. Developmental retardation students' motivation in biology is relatively low, the teacher stated through interviews. Biology is a thematic subject so it is rarely given separately in class. The intensity of a student's motivation will determine the level of learning achievement [18]. Even so, as the research progressed, researchers noticed that there was a high level of curiosity that students showed when learning biology.

TABLE III. OBSERVATION RESULTS LEARNING DIFFICULTIES IN THE ASPECT OF READINESS AND ATTENTION

\begin{tabular}{|c|l|c|}
\hline No & \multicolumn{1}{|c|}{ Question } & Precentage \\
\hline 1 & $\begin{array}{l}\text { Difficulty in understanding the material while learning (Cannot answer when the } \\
\text { teacher asks about the material) }\end{array}$ & $25 \%$ \\
\hline 2 & Already preparing for learning tools in class & $100 \%$ \\
\hline
\end{tabular}


Student readiness and attention are important for the learning process [26]. $63 \%$ is a high score, meaning aspects of readiness and attention do not affect learning difficulties. Students in general have good learning readiness. The condition of students who are ready to receive lessons will try to respond to questions given by the teacher. Readiness is the overall condition of the individual that makes him ready to respond or answer in a certain way towards the situation [2].

The limited intelligence causes mental retardation students have difficulty when receiving material and answering questions from the teacher. [27] stated that with good learning readiness, students can actively participate in learning and easily absorb lessons delivered when in the learning process. For learning readiness that is assisted by parents, retarded students get high scores while those relating to intelligence and themselves have low scores. This is consistent with the results of the teacher questionnaire that is $38.89 \%$ did not agree to the positive statement that was asked. Learning readiness without the help of parents has an influence on student learning difficulties but will have no effect if assisted by parents. Learning assistance from parents is needed for the successful learning of mentally retarded students [25].

TABLE IV. OBSERVATION RESULTS OF LEARNING DIFFICULTIES ASPECTS OF SCHOOL ENVIRONMENT
\begin{tabular}{|c|l|c|}
\hline No & \multicolumn{1}{|c|}{ Question } & Precentage \\
\hline 1 & Interact with other students during breaks & $83 \%$ \\
\hline 2 & Bring textbooks & $0 \%$ \\
\hline
\end{tabular}

The learning environment is a medium for gaining knowledge, understanding, skills and values that lead to maturity [28]. While the school environment itself is the second place of education after the family, where a child will get a lot of new things that are not obtained in the family environment, such as the ability to communicate with teachers and other friends while in school [5]. The school environment is one of the factors affecting the learning difficulties of retarded students which is stated by $42 \%$, and the results of the questionnaire teachers who responded strongly agreed to a positive statement of $44.44 \%$. Even so, for statements about socialization and interaction with others, a high score of $83 \%$ means that mentally disabled students interact well.

The characteristics of retarded students who differ from one student to another make their interaction abilities different. At school, students socialize with other students at rest, however the vocabulary of words that cause less is only among students who can understand it [3]. Based on Table 4, it was found that schools did not prepare biology books for mentally retarded students. The interview results stated that the book has an important role for mentally retarded students for their learning process. The development of students' skills and knowledge can be optimized through the textbook handbook. Textbooks are considered as the heart of educational activities [29]. Short-term memory skills possessed by retarded students cause students to forget, it is in agreement with [2] saying that mentally retarded people are mentally retarded, have a lower intelligence development (IQ) and experience difficulties in the learning process and social adaptation, lower development (IQ) causes subjects to find it difficult to remember something that is abstract and non-repetitive. So the book has a positive role for mentally retarded students.

\section{CONCLUCION}

The learning difficulties of retarded students are influenced by internal factors in the form of aspects of learning readiness and attention that is not with the help of parents. As for learning readiness and attention that relies on the help of parents and aspects of motivation and interest are not included in the factors of student learning difficulties. External factors, the school environment is a factor that affects the learning difficulties of retarded students.

[1] World Health Organization Regional Office for Europe, "Better health , better lives: children and young people with intellectual disabilities and their families," Bucharest Conf., no. September, pp. 2010, [Online]. Available: http://www.euro.who.int/intellectual_disabilities.

[2] S. F. M. SARI, B. BINAHAYATI, and B. M. TAFTAZANI, "Pendidikan Bagi Anak Tuna Grahita (Studi Kasus Tunagrahita Sedang Di Slb N Purwakarta)," Pros. Penelit. dan Pengabdi. Kpd. Masy., vol. 4, no. 2, pp. 217-222, 2017, doi: 10.24198/jppm.v4i2.14273.

[3] WHO, "Chapter 1: Understanding disability," WHO. World Rep. Disabil. Malta WHO, pp. 1-17, 2011, [Online]. Available: http://scholar.google.com/scholar?hl=en\&btnG=Search\&q=intit le:Chapter+1+Understanding+disability\#4.

[4] A. MacLeod, J. Allan, A. Lewis, and C. Robertson, "'Her. come again': the cost of success for higher education students diagnosed with autism," Int. J. Incl. Educ., vol. 22, no. 6, pp. 683-697, 2017, doi: 10.1080/13603116.2017.1396502.

[5] W. L. Wang and C. Y. Kuo, "Relationships Among Teachers' Positive Discipline, Students' Well-being and Teachers' Effective Teaching: A Study of Special Education Teachers and Adolescent Students With Learning Disabilities in Taiwan," Int. J. Disabil. Dev. Educ., vol. 66, no. 1, pp. 82-98, 2018, doi: 10.1080/1034912X.2018.1441978

[6] M. del M. Fernández Fernández and M. P. Jiménez Tejada, "Difficulties learning about the cell. Expectations vs. reality," $J$. Biol. Educ., vol. 53, no. 3, pp. 333-347, 2018, doi: 10.1080/00219266.2018.1469542.

[7] Y. Yusof, C. C. Chan, A. H. Hillaluddin, F. Z. Ahmad Ramli, and Z. Mat Saad, "Improving inclusion of students with disabilities in Malaysian higher education," Disabil. Soc., vol. 0, no. 0, pp. 1-26, 2019, doi: 10.1080/09687599.2019.1667304.

[8] S. Saputri, E. F. Ningsih, and S. Widyawati, "Analisis Kesulitan Anak Tunagrahita Dalam Menyelesaikan Soal Operasi Penjumlahan Di Sekolah Luar Biasa (Slb) Harapan Ibu Metro," MaPan, vol. 5, no. 2, pp. 187-200, 2017, doi: 10.24252/mapan.v5n2a3.

[9] W. Mazher, "Teaching Students with Learning Disabilities to Cope in Middle School," Clear. House A J. Educ. Strateg. Issues Ideas, vol. 91, no. 4-5, pp. 155-167, 2018, doi: 10.1080/00098655.2018.1436822.

[10] A. P. B. Lissa, Lissa; Prasetyo and D. R. Indriyanti, "Pengembangan instrumen penilaian keterampilan berpikir tingkat tinggi materi sistem respirasi dan ekskresi," Lembaran Ilmu Kependidikan, vol. 41, no. 1, 2012. 
[11] M. Kragten, W. Admiraal, and G. Rijlaarsdam, "Students ability to solve process-diagram problems in secondary biology education," J. Biol. Educ., vol. 49, no. 1, pp. 91-103, 2015, doi: $10.1080 / 00219266.2014 .888363$.

[12] L. Luzyawati and H. Hidayah, "Profil Miskonsepsi Siswa dalam Materi Sistem Ekskresi melalui Penugasan Peta Konsep," J. Mangifera Edu, vol. 3, no. 2, pp. 72-87, 2019.

[13] P. Solís, I. Pedrosa, and L. M. Mateos-Fernández, “Assessment and interpretation of teachers' attitudes towards students with disabilities / Evaluación e interpretación de la actitud del profesorado hacia alumnos con discapacidad," Cult. y Educ., vol. 31, no. 3, pp. 576-608, 2019, doi: 10.1080/11356405.2019.1630955.

[14] T. H. E. A. Journal and O. F. Psychiatry, "Classification of Mental Retardation," Dev. Med. Child Neurol., vol. 2, no. 2, pp. 111-112, 1960, doi: 10.1111/j.1469-8749.1960.tb05154.x.

[15] N. Suryani and M. Mumpuniarti, "Kekuatan Kognitif Siswa Tunagrahita Ringan Terhadap Kegiatan Pembelajaran Keterampilan Budidaya Hortikultura," PEMBELAJAR J. Ilmu Pendidikan, Keguruan, dan Pembelajaran, vol. 2, no. 2, p. 101, 2018, doi: 10.26858/pembelajar.v2i2.5760.

[16] C. Neubrand and U. Harms, "Tackling the difficulties in learning evolution: effects of adaptive self-explanation prompts," J. Biol. Educ., vol. 51, no. 4, pp. 336-348, 2016, doi: 10.1080/00219266.2016.1233129.

[17] L. Lissa, "Profil Jenis Pertanyaan Siswa Sma Berdasarkan Taksonomi Bloom Revisi," Edu Sains J. Pendidik. Sains Mat., vol. 5, no. 2, p. 1, 2017, doi: 10.23971/eds.v5i2.731.

[18] P. J. Sainio, K. M. Eklund, T. P. S. Ahonen, and N. H. Kiuru, "The Role of Learning Difficulties in Adolescents' Academic Emotions and Academic Achievement," J. Learn. Disabil., vol. 52, no. 4, pp. 287-298, 2019, doi: 10.1177/0022219419841567.

[19] I. Darimi, "Diagnosis kesulitan belajar siswa dalam pembelajaran aktif di sekolah," J. EDUKASI J. Bimbing. Konseling, vol. 2, no. 1, pp. 30-43, 2016.

[20] R. Upreti and R. Singh, "Impact of Social Class on the Behavioural Skills of Mentally Challenged Children," J. Hum. Ecol., vol. 53, no. 1, pp. 65-73, 2016, doi: 10.1080/09709274.2016.11906957.

[21] S. Grimes, E. Southgate, J. Scevak, and R. Buchanan, "Learning impacts reported by students living with learning challenges/disability," Stud. High. Educ., vol. 0, no. 0, pp. 1-13, 2019, doi: 10.1080/03075079.2019.1661986.

[22] S. Thorne, Interpretive description: Qualitative research for applied practice. Routledge, 2016.

[23] E. Wincup, Criminological research: Understanding qualitative methods. Sage, 2017.

[24] B. Waterfield, B. B. Beagan, and M. Weinberg, "Disabled academics: a case study in Canadian universities," Disabil. Soc., vol. 33, no. 3, pp. 327-348, 2017, doi: 10.1080/09687599.2017.1411251.

[25] C. Wang, K. F. Marsico, and K. A. Do, "Asian American Parents' Beliefs About Helpful Strategies for Addressing Adolescent Mental Health Concerns at Home and School," School Ment. Health, no. 0123456789, 2020, doi: 10.1007/s12310-020-09362-1.

[26] L. Lissa, "Penggunaan Media Kunci Determinasi terhadap Keterampilan Proses Sains Siswa pada Materi Hewan di SMAN 1 Sindang," J. Mangifera Edu, vol. 2, no. 2, pp. 71-78, 2017.

[27] P. Sainio, K. Eklund, R. Hirvonen, T. Ahonen, and N. Kiuru, "Adolescents' Academic Emotions and Academic Achievement Across the Transition to Lower Secondary School: The Role of Learning Difficulties*," Scand. J. Educ. Res., vol. 0, no. 0, pp. 1-19, 2020, doi: 10.1080/00313831.2019.1705900.

[28] Y. P. Xin, M. M. Chiu, R. Tzur, X. Ma, J. Y. Park, and X. Yang, "Linking Teacher-Learner Discourse With Mathematical Reasoning of Students With Learning Disabilities: An Exploratory Study," Learn. Disabil. Q., vol. 43, no. 1, pp. 4356, 2019, doi: 10.1177/0731948719858707.

[29] J. Yamanashi, "The Occupational Therapist's Handbook for Inclusive School Practices.” Taylor \& Francis, 2017. 